\title{
Effect of Seed Bacterization with Fluorescent Pseudomonads on Growth Promotion of Jute (Corchorus olitorius) in Terai Zone of West Bengal
}

\author{
Surajit Khalko $^{1}$, S. Bandyopadhyay ${ }^{1}$ and Anamika Debnath ${ }^{2}$ \\ ${ }^{1}$ Department of Plant Pathology, ${ }^{2}$ AICRP on Spices, Uttar Banga Krishi Viswavidyalaya, \\ Pundibari, Coochbehar, 736165, West Bengal, India \\ *Corresponding author email id:
}

\section{A B S T R A C T}

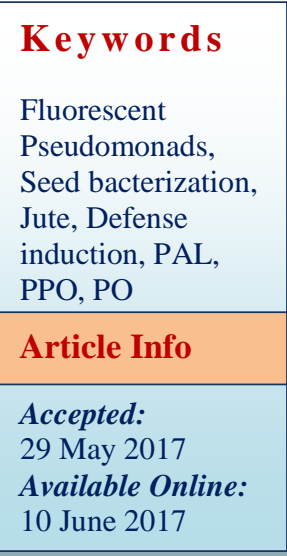

The Fluorescent Pseudomonads were isolated from rhizosphere of fifteen different crops and screened based on their antagonistic effect and effect of metabolites against Jute stem rot pathogen. The five selected isolates were used for seed bacterization to study their effect on seed germination, root length, shoot length and vigour index. The treatment with UBPF20 resulted in $42.41 \%$ increase in root length over control followed by UBPF14 (36.22\%) and UBPF24 (23.83\%). Regarding shoot length all the isolates showed increase in length over control. The isolate UBPF24 increased $47.57 \%$ shoot length over control followed by UBPF20 (27.35\%).The highest vigour index was found with the treatment of UBPF24 (20.96\%) over control followed by UBPF20 (20.18\%) and UBPF14 (19.38\%). Better plant growth was observed in the plants treated with the selected isolates as compared to control. Jute seed treatment with five selected Fluorescent Pseudomonads isolates induced the plant to synthesize defense related enzymes like Phenylalanine Ammonia Lyase (PAL), Poly Phenol Oxidase (PPO) and Peroxidase (PO). The maximum increase in activity of PAL was found in UBPF14 followed by UBPF24 and UBPF18. The isolate UBPF18 showed highest activity of PPO followed by UBPF24, UBPF22 and UBPF14. The activity of PO was also found higher in all the plants treated with isolates than control.

\section{Introduction}

Rhizosphere is a dynamic environment, which harbours diverse group of microbes which directly or indirectly stimulate plant growth, these microbes have been referred as plant growth promoting rhizobacteria (PGPR) (Bloemberg and Lutenberg, 2001). Recently, Fluorescent Pseudomonads are emerging as the largest and potentially most promising group of PGPR (Costacurta and Vanderlenden, 1995) involved in plant growth promotion and plant disease management (Sullivan and Gara, 1992). The first clear indication of improved plant growth and biological control of root pathogens due to seed bacterization with rhizobacteria came from the works of Burr et al., (1978) and Kloepper et al., (1980), they reported the plant growth promoting effects of Pseudomonas strains which were antagonistic to a wide range of plant pathogens in vitro condition. These studies also provided the first evidence that the rhizosphere microbiota could be modified significantly with microorganisms introduced with the planting material. The use of selected microbial antagonists for control of soil-borne 
phytopathogens has been widely studied but there are few commercial products yet available. The potential shown by some Pseudomonas isolates for control of intractable soil-borne phytopathogens made several attempts at development of seed coating techniques, with mixed levels of success (Slininger et al., 1996; Shah-Smith and Burns 1997; Moenne-Loccoz et al., 1999). The present paper reports effect of seed bacterization with Fluorescent Pseudomonads on growth promotion of jute (C. olitorius).

\section{Materials and Methods}

\section{Preparation of talc based formulation}

Different promising strains of Fluorescent Pseudomonads (UBPF 14, UBPF18, UBPF20, UBPF22 and UBPF24) collected from Department of Plant Pathology; UBKV was inoculated to nutrient broth separately and incubated in a rotary shaker at $150 \mathrm{rpm}$ for 48 $\mathrm{h}$ at room temperature $\left(28 \pm 2^{\circ} \mathrm{C}\right)$. After $48 \mathrm{~h}$ of incubation, the broth containing $9 \times 10^{8}$ $\mathrm{cfu} / \mathrm{ml}$ was used for the preparation of talc based formulation. To $400 \mathrm{ml}$ of bacterial suspension, one $\mathrm{kg}$ of the purified talc powder (sterilized at $105^{\circ} \mathrm{C}$ for $12 \mathrm{~h}$ ) $15 \mathrm{~g}$ calcium carbonate (to adjust the $\mathrm{pH}$ to neutral) and 10 $\mathrm{g}$ of carboxy methyl cellulose (CMC) as an adhesive were mixed under aseptic conditions following the method described by Vidhyasekaran and Muthamilan (1995).

\section{Seed bacterization}

The rhizobacterial isolates were bioassayed for their ability to promote / inhibit seedling growth using the methods as described by Shende et al., (1977) and Elloit and Lynch (1984) with few modifications. Jute seeds (JRO- 128) were surface sterilized with $0.1 \%$ $\mathrm{HgCl}_{2}$ for three minutes followed by three successive washing with sterile water and the water is decanted. Seeds were then treated with talc based formulation of the isolates prepared by mixing the cultures (grown in liquid medium for 48 hours containing at least $10^{6}$ cells $/ \mathrm{ml}$ ) with talc. The treated seeds were placed on moist blotting paper in Petri dishes and allowed for 2-3days for germination. Three replicates were used for each treatment. The data on germination were recorded after 3 days. Seeds without treatments placed on moist blotting paper were used as control plates.

\section{Pot experiment}

Another set of experiment was conducted on pot to record the effect of seed bacterization on the root length, shoot length and germination for which vigour index was calculated.

\section{Preparation of inoculum}

To study the effect of treatment by some selected rhizobacterial isolates in pot trial the pathogen Macrophomina phaseoliona was multiplied in sand- maize meal. At first the sand and grinded maize was mixed at 1:1 ratio maintaining some moisture in the mixture. Then discs of the pathogen were inoculated in the mixture separately in poly propylene packet and allowed to incubate at $28+1{ }^{\circ} \mathrm{C}$ for 3 to 4 days. After the growth of the pathogen in the sand-maize meal, the mixture is mixed thoroughly in pot soil. The seeds of jute treated with some selected isolates were sown in the pots containing the inoculum of the pathogen. The results of germination, vigour index and enzyme production were recorded further.

\section{Estimation of Phenylalanine Ammonia Lyase (PAL)}

To prepare the enzyme extract $500 \mathrm{mg}$ of plant material was homogenized in $0.5 \mathrm{ml}$ of 
cold $25 \mathrm{mM}$ borate $\mathrm{HCl}$ buffer ( $\mathrm{pH} 8.8$ ) containing $5 \mathrm{mM}$ mercaptaethanol $(0.4 \mathrm{ml} / \mathrm{lit})$. The homogenate was centrifuged at 12,000 $\mathrm{rpm}$ for 20 minutes. Thus, the supernatant obtained was used as enzyme source. In a test tube $0.3 \mathrm{ml}$ borate buffer $(0.2 \mathrm{M}), 0.2 \mathrm{ml}$ supernatant and $1.3 \mathrm{ml}$ distilled water were taken using micropipette. The reaction was initiated by adding $1 \mathrm{ml}$ L-Phenyl alanine solution $(0.1 \mathrm{M})$ and allowed to incubate at 32 ${ }^{\circ} \mathrm{C}$ for 30 minutes. Then the reaction was stopped by the addition of $0.5 \mathrm{ml}$ of Trichloroacetic acid (1M). A control was run by addition of $\mathrm{L}$ phenyl alanine after Trichloroacetic acid. The absorbance was measured at $290 \mathrm{~nm}$ in spectrophotometer. A standard graph was prepared using Trans cinnamic acid for comparison. Enzyme activity was expressed as change in absorbance min-1 g-1 tissue (Brueske, 1980).

\section{Estimation of Peroxidase (PO)}

The enzyme extract was prepared by taking 1 $\mathrm{g}$ of fresh plant tissue in $3 \mathrm{ml}$ of $0.1 \mathrm{M}$ phosphate buffer) ( $\mathrm{pH} 7)$ by grinding with a pre cooled mortar and pestle and the homogenate was centrifuged at $18,000 \mathrm{rpm}$ at $5^{\circ} \mathrm{C}$ for 15 minutes. The supernatant was used as enzyme source.

In a cuvette $3 \mathrm{ml}$ buffer solution, $0.05 \mathrm{ml}$ guaiacol solution, $0.1 \mathrm{ml}$ supernatant and $0.03 \mathrm{ml}$ hydrogen peroxide were taken by using micropipette and were mixed well. Therefore the cuvette was placed in the Spectrophotometer and the absorbance was measured at $490 \mathrm{~nm}$ after five minutes interval. Enzyme activity was expressed as change in absorbance min-1 g-1 tissue (Malik and Singh, 1980).

\section{Estimation of Poly Phenol Oxidase (PPO)}

The enzyme extract was prepared by taking $0.2 \mathrm{~g}$ leaf samples and $2 \mathrm{ml}$ of $0.1 \mathrm{M}$ sodium phosphate buffer by crushing. The homogenate was centrifuged at $16,000 \mathrm{rpm}$ for $15 \mathrm{~min}$ at $4^{\circ} \mathrm{C}$. The supernatant was used as enzyme source. The reaction mixture consisted of $200 \mu \mathrm{l}$ of the enzyme extract and $1.5 \mathrm{ml}$ of $0.1 \mathrm{M}$ sodium phosphate buffer $(\mathrm{pH}$ 6.5). To start the reaction, $200 \mu \mathrm{l}$ of $0.01 \mathrm{M}$ catechol was added, and activity was expressed as changes in absorbance at $495 \mathrm{~nm}$ $\min ^{-1} \mathrm{~g}^{-1}$ tissue (Mayer et al., 1965).

\section{Results and Discussion}

\section{Plant growth promotion}

The five isolates screened based on their antagonistic effect and effect of metabolites against three selected fungal plant pathogens were used for seed dressing to study their effect on seed germination, root length, shoot length and vigour index. The jute seeds were treated by the talc based formulation of the five selected isolates and the results obtained are presented in table 1. All the five isolates showed better germination than the untreated seeds. Among them UBPF14 was found to give highest germination (95\%) as compared to others. Besides, the isolates were also found to give increased root length over untreated seeds. The treatment with UBPF20 resulted in $42.41 \%$ increase in root length over control followed by UBPF14 (36.22\%) and UBPF24 (23.83\%). Regarding shoot length all the isolates showed increase in length over control. The isolate UBPF24 increased $47.57 \%$ shoot length over control followed byUBPF20 (27.35\%). The vigour index calculated from the data on germination, root length and shoot length revealed that all the isolates gave better vigour index as compared to untreated check. The highest vigour index was found with the treatment of UBPF24 (20.96\%) control followed by UBPF20 (20.18\%) and UBPF14 (19.38\%). Better plant growth was observed in the plants treated with the selected isolates 
as compared to control pots. The findings support the findings of Vidyasekaran (1998), which states that plant growth promoting rhizobacteria including Fluorescent Pseudomonads promote plant growth by secreting auxins gibberellins and cytokinins (). It is reported that due to addition of PGPR plant growth is benefited by the increase in germination rates and root growth (Lucy et al., 2004). In the present study also the germination and root growth were enhanced. Begum et al., (2003) reported that colonization of some rhizobacterial isolates reduced the incidence of seed mycoflora which indirectly enhanced the per cent seed germination and vigour index of seedlings. Singh et. al. (2008) reported that seeds coated with Pseudomonas fluorescens showed significant increase in radicle length and higher vigour index. The present investigation also supports the previous works on growth promotion by the rhizobacterial isolates in terms of germination of seeds, root and shoot growth and vigour index. This type of result may be due to the several reasons like reduced incidence of seed and soil mycoflora, increased uptake of nutrients, synthesis of some compounds by the bacterium or enhanced synthesis of growth hormones.

Table.1 Effect of seed bacterization on root length, shoot length and germination percentage on jute seeds

\begin{tabular}{cccccccc}
\hline Isolates & $\begin{array}{c}\text { Germination } \\
\text { percentage } \\
(\%)\end{array}$ & $\begin{array}{c}\text { Increase of } \\
\text { germination } \\
\text { percentage } \\
\text { over } \\
\text { control }\end{array}$ & $\begin{array}{c}\text { Root } \\
\text { length } \\
(\mathrm{cm})\end{array}$ & $\begin{array}{c}\text { Increase } \\
\text { of root } \\
\text { length } \\
\text { over } \\
\text { control }\end{array}$ & $\begin{array}{c}\text { Shoot } \\
\text { length } \\
(\mathrm{cm})\end{array}$ & $\begin{array}{c}\text { Increase } \\
\text { of shoot } \\
\text { length } \\
\text { over } \\
\text { control }\end{array}$ & $\begin{array}{c}\text { Vigour } \\
\text { index }\end{array}$ \\
\hline UBPF14 & 95 & 26.66 & 4.40 & 36.22 & 16.00 & 14.28 & 19.38 \\
UBPF18 & 90 & 20.00 & 3.83 & 18.57 & 14.16 & 1.14 & 16.19 \\
UBPF20 & 90 & 20.00 & 4.60 & 42.41 & 17.83 & 27.35 & 20.18 \\
UBPF22 & 80 & 6.66 & 3.86 & 19.50 & 15.73 & 12.35 & 15.67 \\
UBPF24 & 85 & 13.33 & 4.00 & 23.83 & 20.66 & 47.57 & 20.96 \\
Control & 75 & - & 3.23 & & 14.00 & - & 12.92 \\
\hline SEm \pm & & & 0.4150 & & 1.8383 & & \\
CD $(0.05)$ & & & 0.9042 & & 4.0053 & & \\
CV\% & & & 12.74 & & 13.73 & & \\
\hline
\end{tabular}

Fig.1 Changes in Phenylalanine Ammonia Lyase (PAL) activity by isolates of Fluorescent Pseudomionads in Jute against Macrophomina phaseolina

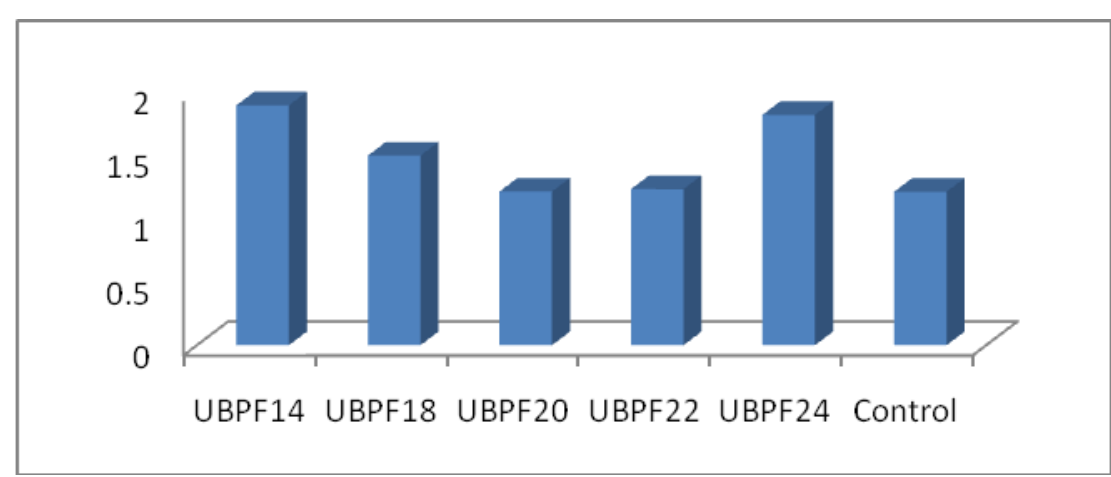


Fig.2 Changes in Poly Phenol Oxidase (PPO) activity by isolates of Fluorescent Pseudomionads in Jute against Macrophomina phaseolina

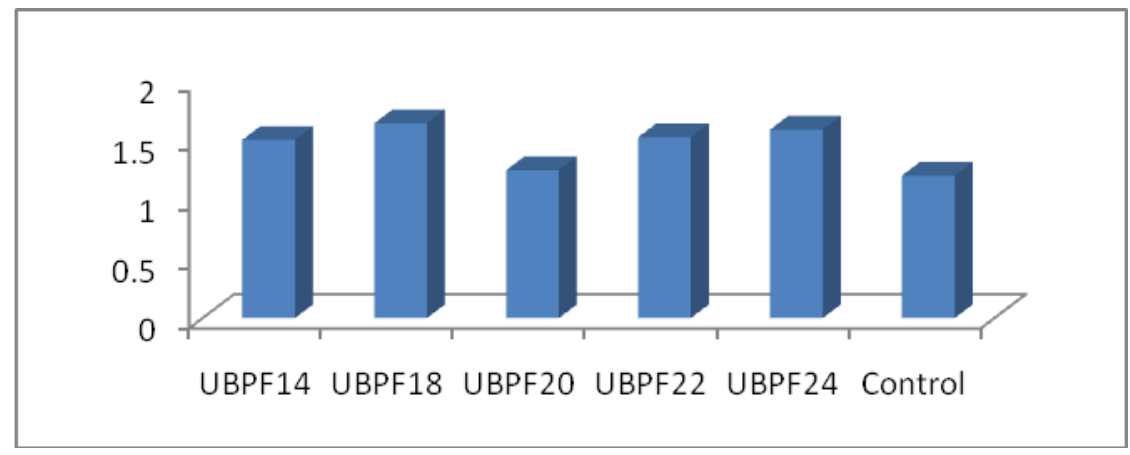

Fig.3 Changes in Peroxidase (PO) activity by isolates of Fluorescent Pseudomionads in Jute against Macrophomina phaseolina

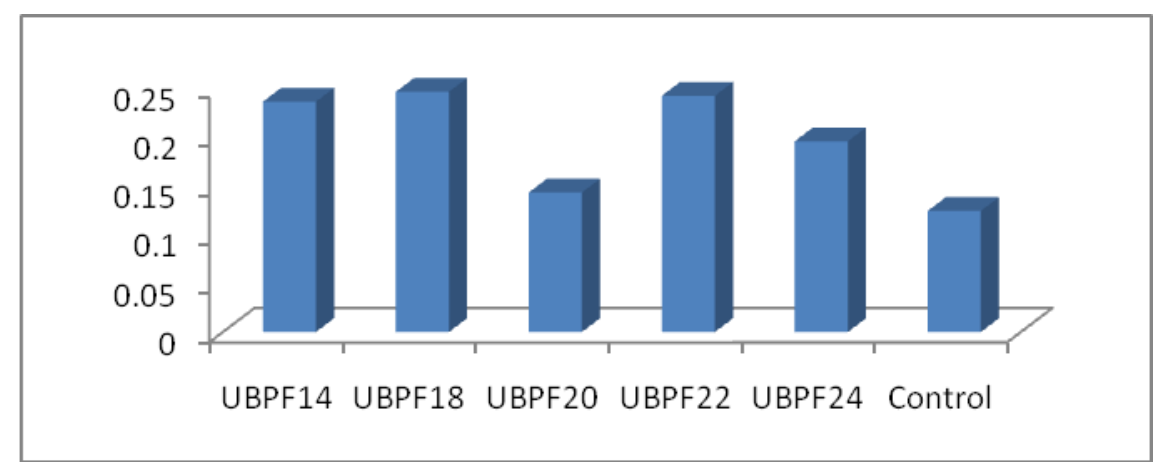

\section{Induction of defense related enzymes}

Jute seed treatment with Fluorescent Pseudomonads isolates induced the plant to synthesize Phenylalanine Ammonia Lyase (PAL), Poly Phenol Oxidase (PPO) and Peroxidase (PO). The enzyme activity was recorded as change in absorbance per minute per gram fresh weight. The increase in the synthesis of defense related enzymes were observed in almost all the plants treated with isolates after challenge inoculation with Macrophomina phaseolina. The maximum increase in activity of PAL was found in UBPF14 followed by UBPF24 and UBPF18 (Fig. 1). The increased activity of PPO was observed in all the isolates as compared to control (Fig. 2). The isolate UBPF18 showed highest activity of PPO followed by UBPF24,
UBPF22 and UBPF14. The activity of PO was also found higher in all the plants treated with isolates than control (Fig. 3). The isolates UBPF24 and UBPF20 also showed higher activity of the enzyme PO. Therefore all the isolates showed increased activity of defense related enzymes viz., PAL, PO and PPO. Similarly PPO and PO catalyse the last step in the biosynthesis of lignin and other oxidative phenol. Phenolic compounds may be fungitoxic in nature and may increase the mechanical strength of the host cell wall. The studies have shown that PAL activity is induced in plants upon treatment with Pseudomonas fluorescens (Chen et al., 2000). Peroxidase represents another component of an early response in plants to pathogen attack and plays a key role in the biosynthesis of lignin which limits the extent of pathogen 
spread (Bruce and West, 1989). Induced activity of PPO by Pseudomonas fluorescens against different pathogens have been reported by several workers (Meena et. al., 2000; Chen et. al., 2000). In the present study all the selected isolates of Fluorescent Pseudomonads were found to show increased activity of the defence related enzymes viz. PAL, PPO and PO which is supporting the previous works on production of defence related enzymes by the treatment with Fluorescent Pseudomonads.

From the present discussion it can be concluded that the highest germination and higher plant vigour of jute seed was found in seeds bacterized with Fluorescent Pseudomonads viz. UBPF14, UBPF20 and UBPF18 as a result of seed bacterization by the isolates. All the isolates of Fluorescent Pseudomonads increased the activity of defense related enzymes such as PAL, PPO and PO. However, the highest activity of PAL was found in UBPF14 and, UBPF18 showed highest activity of PPO and PO. The overall efficacy of the five selected isolates Fluorescent Pseudomonads reveals that the isolate UBPF24 is the most efficient isolate to be used as bio-control agent as well as PGPR.

\section{References}

Bakker, P.A.H.H., Van Peer, R. and Schippeers, B. 1991. Suppression of soil borne plant pathogens by Fluorescent Pseudomonads; Mechanism and prospect. In: Development in agriculturally forest ecology edited by Beemester, R.A.B., Bollen, G.J.M., Gerlach, M., Ruissen, A., Schippers, B. and Temple, A. (Elsvier, Amsterdam), pp. 217-230.

Begum Mashooda, Ravisankar Rai, V. and Lokesh, S. 2003. Effect of plant growth promoting rhizobacteria on seed borne fungal pathogens in okra. Indian Phytopathlogy. 56 (2): 156-158

Bloemberg, G.V. and Lutenberg, B.J.J. 2001. Molecular basis of plant growth promotion and biocontrol by rhizobacteria, Curr Opin Plant Biology. 4: 343-350

Bruce, R.J. and West, C.A. 1989. Elicitation of lignin biosynthesis and isoperoxidase activity by pectic fragments in suspension cultures of castor bean. Plant Physiol. 91 (3): 889 - 897.

Brueske, C.H. 1980. Phenylalanine ammonialyase activity in Lycopersicon esculentum roots infected and resistant to the root knot nematode, Meloidogyne incognita. Physiology and Plant Pathology. 16: 409-414.

Burr, T.J., Schroth, M.N. and Suslow, T.V. 1978. Increased potato yields by treatment of seed pieces with specific strains of Pseudomonas fluorescens and P. putida. Phytopathology. 68: 13771383.

Chen, C., Belanger, R.R., Benhamou, N. and Paulitz, T, 2000. Defense enzymes induced in cucumber roots by treatment with plant growth promoting rhizobacteria (PGPR) and Pythium aphanidermatum. Physiology Molecular Plant Pathology. 56: 13-23.

Costacurta, A. and Vanderlenden, J. 1995. Synthesis of phytohormones by plant associated bacteria. Crit. Review Microbial. 21: 1-18.

Cronin, D., Moenne Loccoz, Y., Fenton, A., Dunne, C., Dowling, D.N. and Gara, O.F. 1997. Role of 2,4diacetylphloroglucinol in the interactions of the biocontrol pseudomonad strain F113 with the potato cyst nematode Globodera rostochiensis. Applied Environmental Microbiology. 63: 1357-1361.

Fenton, A.M., Stephens, P.M., Crowley, J. O., Callaghan, M. and Gara, O' F. 1992. 
Exploitation of gene(s) involved in 2,4diacetylphloroglucinol biosynthesis to confer a new biocontrol capability to a Pseudomonas strain. Applied and Environmental Microbiology. 58: 38733878 .

Frankenberger, Jr. and Arshad, M. 1995. Phytohormones in soils, in microbial production and functions, edited by Frankenberger $\mathrm{W} \mathrm{T}$ and Arshad $\mathrm{M}$ (mercek, Dekker, New York), pp. 503518.

Glick, B.R., Jacobson, C.B., Schwarze, M.M.K. and Pastermak, J.J. 1994. 1aminocyclopropen-1 carboxylic acid deaminase mutants of the plant growth promoting rhizobacteria; Pseudomonas putida Gr-12-2 do not stimulate canola root elongation. Can. J. Microbial. 40: 911-915.

Glick, B.R., Patten, C.L., Holguin, G. and Penrose, D.M. 1999. Biochemical and Genetic Mechanisms used by Plant Growth Promoting Bacteria. Imperial College Press.

Kloepper, J.W., Leong, J., Teintze, M. and Schroth, M.N. 1980. Pseudomonas siderophores: a mechanism explaining disease suppressive soils. Curr. Microbiology. 4: 317-320.

Lucy, M., Reed, E. and Glick, B.R. 2004. Application of free living plant growth promoting rhizobacteria. Antonie Van Leeuwenhoek, 86: 1-25.

Malik, C.P. and Singh, M.B. 1980. In: Plant Enzymology and Histoenzymology, Kalyani publishers, New Delhi, p 53.

Mayer, A.M., Harel, E. and Shaul, R.B. 1965. Assay of catechol oxidase, a critical comparison of methods. Phytochemistry. 5: 783-789.

McIntyre, J.L. and Press, L.S. 1991. Formulation, delivery systems and marketing of biocontrol agents and plant growth promoting rhizobacteria (PGPR). In: Baker RR, Dunn PE ed.
The Rhizosphere and Plant Growth. BARC Beltsville Symposium on Agricultural Research No 14. Kluwer Academic, Dordrecht, The Netherlands, pp. 289-295

Meena, B., Radhajeyalakshmi, R., Marimuthu, T., Vidhyasekaran, P., Doraisamy, S. and Velazhahan, R. 2000. Induction of pathogenesis-related proteins, phenolics and phenylalanine ammonia lyase in groundnut by Pseudomonas fluorescens. Journal of Plant Disease and Protection. 107: 514-527

O'Sullivan, D.J. and O'Gara, F. 1992. Traits of fluorescent Pseudomonands spp. Involved in suppression of plant root pathogens. Microbiology Review. 56: 662-676

Shah-Smith, D.A. and Burns, R.G. 1997. Shelf-life of a biocontrol Pseudomonas putida applied to sugar beet seeds using commercial coatings. Biocontrol Science and Technology. 7: 65-74.

Shanahan, P., Sullivan, O' D.J., Simpson, P., Glennon, J.D. and O'Gara, F. 1992. Isolation of 2,4-diacetylphloroglucinol from a fluorescent pseudomonad and investigation of physiological parameters influencing its production. Applied and Environmental Microbiology. 45: 353-358

Shende, S.T., Apte, R.G. and Singh, T. 1977. Influence of Azotobacter on germination of rice and cotton seeds. Curr. Science. 46 (19): 675-676.

Sindhu, S.S., Suneja, S. and Dadarwall, K.R. 1997. Plant growth promoting rhizobacteria and their role in crop productivity. In: Biotechonogical approaches in soil microorganism for sustainable crop production, edited by Dadarwall K.R. (Scientific publisher, Jodhpur), pp. 149-170.

Singh, V., Ranaware, A.M. and Nimbka, N. 2008. Bioefficacy of antagonists against 
root-rot fungus Macrophomina phaseolina of safflower. In: Proceedings of $7^{\text {th }}$ International Safflower Conference on 'Safflower: Unexploited potential and world adaptibility held on 3-6 November, 2008 at Wagga Wagga, NSW, Australia. Slininger, P.J., van Cauwenberge, J.E., Bothast, R.J., Weller, D.M., Thomashow, L.S, and Cook, R.J. 1996. Effect of growth culture physiological state, metabolites, and formulation on the viability, phytotoxicity, and efficacy of the take-all biocontrol Pseudomonas fluorescens 2-79 stored encapsulated on wheat seeds. Applied Microbiology and Biotechnology. 45: 391-398.
Vidhyasekaran, P. 1998. Biological suppression of major diseases of field crops using bacterial antagonists. In: Biological Suppression of Plant Disease, Phytoparasitic Nematodes and Weeds (Eds..) In: Singh, S.P. and Hussaini, S.S.(Eds.), National seminar on Biological suppression of plant disease, phytoparasitic nematodes and weeds - present scenario and future thrust. Project Directorate of Biological Control, Bangalore, India, pp. 81-95.

Vidyasekaran, P. and Muthamilan, M. 1995.

Development of formulations of Pseudomonas fluorescens for control of chickpea wilt. Plant Disease.79:782786.

\section{How to cite this article:}

Surajit Khalko, S. Bandyopadhyay and Anamika Debnath. 2017. Effect of Seed Bacterization with Fluorescent Pseudomonads on Growth Promotion of Jute (Corchorus olitorius) in Terai Zone of West Bengal. Int.J.Curr.Microbiol.App.Sci. 6(6): 3036-3043.

doi: https://doi.org/10.20546/ijcmas.2017.606.361 